\title{
Erratum to: Hepatic effects of Cimicifuga racemosa extract in vivo and in vitro
}

\author{
S. Lüde $\cdot$ M. Török $\cdot$ S. Dieterle $\cdot$ A. C. Knapp $\cdot$ \\ R. Kaeufeler $\cdot$ R. Jäggi $\cdot$ U. Spornitz $\cdot$ \\ S. Krähenbühl
}

Published online: 26 May 2010

(C) Springer Basel AG 2010

\section{Erratum to: Cell Mol Life Sci (2007) 64:2848-2857 \\ DOI 10.1007/s00018-007-7368-4}

In the abstract the correct dose in the sentence "Microvesicular steatosis was found in rats treated with $>500 \mu \mathrm{g} / \mathrm{kg}$ body weight cimicifuga extract." should be $1,000 \mathrm{mg} / \mathrm{kg}$ body weight (instead of $>500 \mu \mathrm{g} / \mathrm{kg}$ ). The corresponding dose in the results part of the article is cited correctly.

The authors apologize for this error and any confusion it may have caused.

The online version of the original article can be found under doi:10.1007/s00018-007-7368-4.

S. Lüde · M. Török · S. Dieterle · A. C. Knapp ·

S. Krähenbühl $(\square)$

Division of Clinical Pharmacology \& Toxicology

and Department of Research, University Hospital Basel,

4031 Basel, Switzerland

e-mail: kraehenbuehl@uhbs.ch

R. Kaeufeler

Max Zeller Söhne AG, Romanshorn, Switzerland

R. Jäggi

Vitaplant Ltd., Witterswil, Switzerland

U. Spornitz

Institute for Anatomy, Histology and Embryology,

University of Basel, Basel, Switzerland 